\title{
An exploration study on detecting important factors influencing brand loyalty in retail stores
}

\author{
Naser Azad", Hanieh Kasehchi, Hamed Asgari and Hamid Bagheri
}

Department of Management, Islamic Azad University, South Tehran Branch, Tehran, Iran

\section{H R O N I C L E A B S T R A C T}

Article history:

Received May 12, 2013

Accepted July 15, 2013

Available online

July 202013

Keywords:

Retail stores

Brand loyalty

Factor analysis

\begin{abstract}
Brand loyalty is one of the most important factors influencing on the success of retail stores. Many retail stores in the field of sport shoes in city of Tehran, Iran are facing tight competition and there seems to be that only stores with loyal customers could survive. In this paper, we present an exploration study to find out important factors influencing retail stores selling one of well-known sport shows such as Adidas, Nike, etc. in city of Tehran, Iran. The proposed study designs a questionnaire in Likert scale and distributes among 265 regular customers of these stores and analyze them using factor analysis. The results indicate that there were four important factors influencing customer loyalty including brand identification, brand promotion, brand loyalty and characterization of stores.
\end{abstract}

(C) 2014 Growing Science Ltd. All rights reserved.

\section{Introduction}

With the growing realization that brand is one of the most valuable intangible assets, branding has changed as a top management priority during the last decade. In fact, during the past few years, there has been a growing competition in global market and branding can be especially important in the retailing industry to affect customer perceptions and drive store choice and loyalty. Runyan and Droge (2008), for instance, presented an extensive review of 20+ years of research on small, independent retailers and investigated on 134 different articles. Ailawadi and Keller (2004) integrated different lessons from branding and retail image research to present a better understanding of how retailers generate their brand images, paying more attention to the role of the manufacturer and private label brand assortment. The other issue on global market is to understand different sources of sustained competitive advantage, which are major areas of research in strategic management.

\footnotetext{
* Corresponding author.

E-mail addresses: dr.naserazad@yahoo.com (N. Azad)

C 2013 Growing Science Ltd. All rights reserved doi: $10.5267 /$ j.ds1.2013.07.005
} 
Barney (1991) examined the relationship between firm resources and sustained competitive advantage and discussed different empirical indicators to generate sustained competitive advantagevalue, rareness, imitability, and substitutability. Dolich (1969) explained that there are some congruence relationships between self-image and product brands.

Branding has become a top management priority during the past few years because of the growing realization that brand is one of the most remarkable intangible assets (Elliott and Wattanasuwan, 1998; Levy, 1999). Keller and Lehmann (2006) identified some of the influential work in the branding area, giving insights on different achievements such as brand positioning, brand integration, brand-equity measurement, brand growth, and brand management. They also discussed some existing gaps in the research of branding and brand equity. Turley and Milliman (2000) concentrated on the research accomplished over the years on the impacts of facility-based environmental cues, or "atmospherics", on buyer behavior. They reviewed the pertinent literature by building a comprehensive table of the empirical investigations in this area that focused on the different findings. This summary table showed that atmospheric variables affect a wide variety of consumer evaluations and behaviors.

Kwon and Lennon (2009) performed two experiments to disentangle reciprocal relationships between multichannel retailers' offline and online brand images. Their results supported the cross-channel impact of prior offline brand image on online brand beliefs and that of online performance on offline brand beliefs. Consumers' online and offline brand attitudes were impacted by not only brand beliefs from the respective channel but also by beliefs from the other channel. However, strong prior offline brand image was detected to mitigate the effect of online performance on offline brand beliefs in the presence of negative online performance as a way to remove cognitive dissonance.

Chaudhuri and Holbrook (2001) investigated the role of brand loyalty by looking into the chain of effects from brand trust and brand influence on brand performance. Their model included productlevel, category-related controls and brand-level controls. They compiled an aggregate data set for 107 brands from three separate surveys of consumers and brand managers. Their results indicated that when the product- and brand-level variables were controlled for, brand trust and brand affect combined to determine purchase loyalty and attitudinal loyalty.

\section{The proposed study}

This paper presents an exploration study to find out important factors influencing retail stores selling one of well-known sport shows such as Adidas, Nike, etc. in city of Tehran, Iran. The proposed study designs a questionnaire in Likert scale. The population size is determined as follows,

$$
N=Z_{\alpha / 2}^{2} \frac{p \times q}{e^{2}},
$$

where $N$ is the sample size, $p=1-q$ represents the probability, $z_{\alpha / 2}$ is CDF of normal distribution and finally $\varepsilon$ is the error term. For our study we assume $p=0.5, z_{\alpha / 2}=1.96$ and $e=0.99$, the number of sample size is calculated as $N=265$. We have distributed 265 questionnaire and received 234 ones. The questionnaire consists of 24 questions and we use factor analysis to perform the survey. Cronbach alpha has been calculated as 0.894 , which is well above the minimum acceptable limit of 0.70 and we can confirm the reliability of the questionnaire.

Table 1 demonstrates the summary of basic statistics, which helps us detect unusual variables. As we can observe from the results of Table 1, none of the variables has any biad skewness and there is no need to remove any variable from our survey. In addition, Kaiser-Meyer-Olkin Measure of Samplng (KMO) is about 0.89 , which means it is possible to extract factors from this questionnaire. 
Table 1

The summary of basic statistics

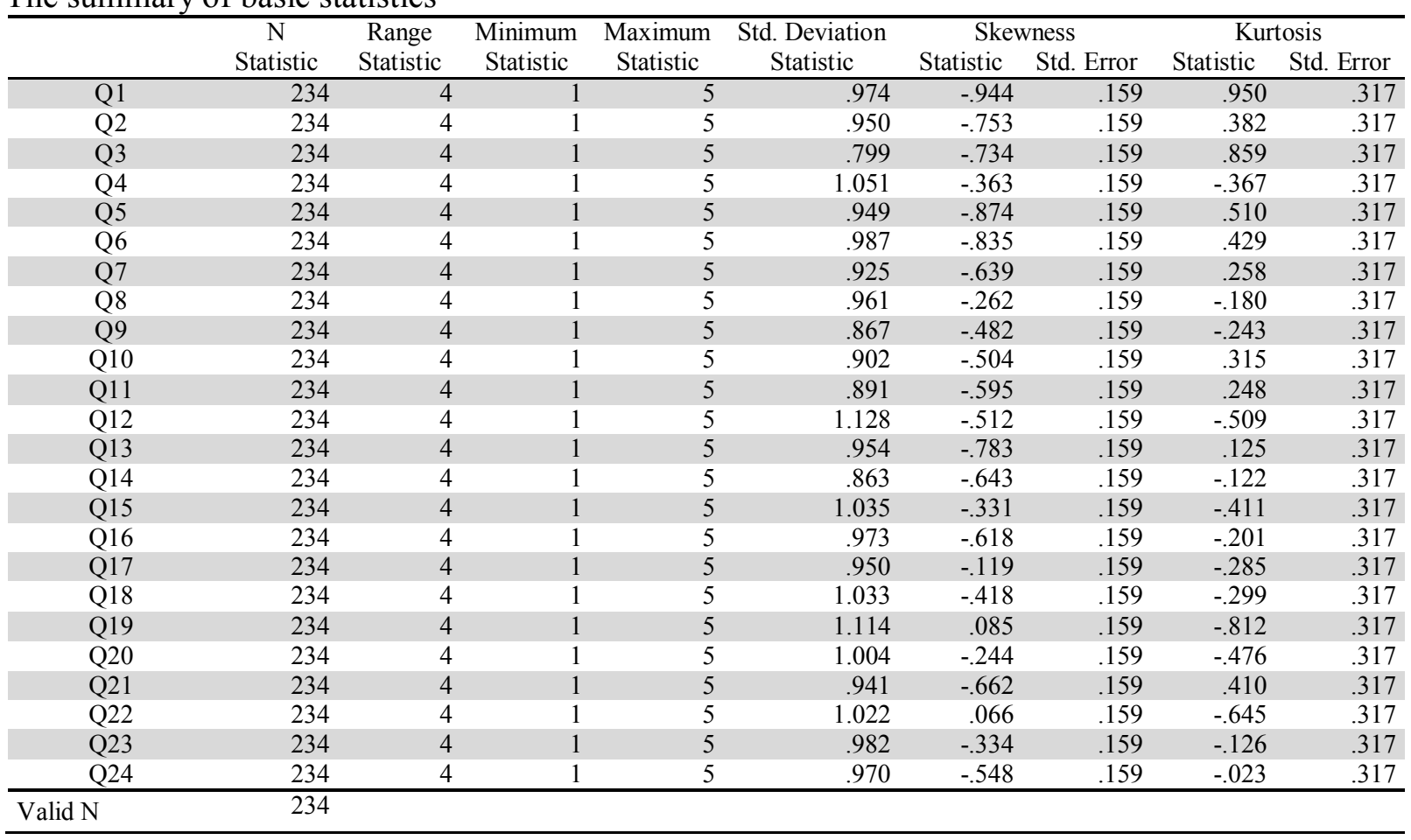

\section{The results}

In this section, we present details of our findings on the implementation of factor analysis summarized in Table 2 as follows,

Table 2

The summary of factor analysis

\begin{tabular}{|c|c|c|c|c|c|}
\hline Factor & Measured variable & Weight & Eigenvalue & Variance & Acc. \\
\hline \multirow[t]{7}{*}{ Identification } & Brand bias & 0.695 & 3.623 & 15.096 & 15.096 \\
\hline & People's opinion toward brand & 0.682 & & & \\
\hline & Consistency between customer values with brand & 0.681 & & & \\
\hline & Defending the brand & 0.669 & & & \\
\hline & Feeling superiority towards other brands & 0.652 & & & \\
\hline & Consistency between stores' objectives with social benefits & 0.61 & & & \\
\hline & Improvement on users' social relationships by Brand & 0.574 & & & \\
\hline \multirow[t]{7}{*}{ Promotion } & Brand identity & 0.761 & 3.532 & 14.717 & 29.813 \\
\hline & Brand Communications & 0.73 & & & \\
\hline & Promotion through brand & 0.728 & & & \\
\hline & Consistency between user's personal characteristics with brand & 0.716 & & & \\
\hline & Compatibility of users' mentality with brand & 0.681 & & & \\
\hline & Brand Integrity & 0.443 & & & \\
\hline & Help grow the brand & 0.418 & & & \\
\hline \multirow[t]{6}{*}{ Loyalty } & Feel proud of store brand & 0.427 & 3.134 & 13.06 & 42.872 \\
\hline & Word of mouth advertisement & 0.731 & & & \\
\hline & Brand commitment to customer ideas & 0.705 & & & \\
\hline & Stores' perception on people's needs & 0.594 & & & \\
\hline & Shared by Store Brand & 0.529 & & & \\
\hline & Having friendship relationship with users & 0.469 & & & \\
\hline \multirow{3}{*}{$\begin{array}{l}\text { Store } \\
\text { characteristics }\end{array}$} & Diversity in products & 0.793 & 2.212 & 9.216 & 52.088 \\
\hline & Market share of the store & 0.741 & & & \\
\hline & The purchase cost & 0.542 & & & \\
\hline
\end{tabular}




\section{Discussion and conclusion}

Building a good brand is the key factor for the success of any business unit. Retail stores are considered as primary suppliers of sport shows in city of Tehran, Iran. Therefore, it is important to find out about important factors influencing the success of these stores. Using factor analysis, the proposed study of this paper performed an empirical investigation to find out more about important factors influencing the success of retail stores. The study has detected four factors including brand identification, brand promotion, brand loyalty and characteristics of retail stores.

The first factor, brand identification, consists of six factors including brand bias, people's opinion toward brand, consistency between customer values with brand, defending the brand, feeling superiority towards other brands, consistency between stores' objectives with social benefits and improvement on users' social relationships by brand.

The second factor is associated with brand promotion and there are seven factors play essential role on this factor. These issues include seven factors where brand identity, brand Communications and promotion through brand are the most important influential sub-factor.

The third factor is related to brand loyalty with seven factors where feel proud of store brand, word of mouth advertisement and brand commitment to customer ideas are the most important ones.

Finally, store characteristic is the last influential factor with three components. In our survey, customers' ease of choice in terms of product diversification is the most important factor. In addition, the more market share a retail store gain, the more attractive the retail store is. Finally, the purchase cost is the last important factor and the less consumer spend on quality product, the more likely they repurchase.

\section{Acknowledgment}

The authors would like to thank the anonymous referees for constructive comments on earlier version of this paper.

\section{References}

Ailawadi, K. L., \& Keller, K. L. (2004). Understanding retail branding: conceptual insights and research priorities. Journal of retailing, 80(4), 331-342.

Barney, J. (1991). Firm resources and sustained competitive advantage. Journal of management, 17(1), 99-120.

Chaudhuri, A., \& Holbrook, M. B. (2001). The chain of effects from brand trust and brand affect to brand performance: the role of brand loyalty. The Journal of Marketing, 81-93.

Dolich, I. J. (1969). Congruence relationships between self images and product brands. Journal of Marketing Research, 80-84.

Elliott, R., \& Wattanasuwan, K. (1998). Brands as symbolic resources for the construction of identity. International journal of Advertising, 17, 131-144.

Keller, K. L., \& Lehmann, D. R. (2006). Brands and branding: Research findings and future priorities. Marketing Science, 25(6), 740-759.

Kwon, W. S., \& Lennon, S. J. (2009). Reciprocal effects between multichannel retailers' offline and online brand images. Journal of Retailing, 85(3), 376-390.

Levy, S. J. (1999). Symbols for sale. reprinted in: Brands, Consumers, Symbols \& Research, 203212.

Runyan, R. C., \& Droge, C. (2008). A categorization of small retailer research streams: what does it portend for future research?. Journal of Retailing, 84(1), 77-94.

Turley, L. W., \& Milliman, R. E. (2000). Atmospheric effects on shopping behavior: a review of the experimental evidence. Journal of Business Research, 49(2), 193-211. 